Alimentation

NU'TRITION AND FEEDING

A. - Utilisation des céréales

Utilization of cereals

\title{
VALEUR ALIMENTAIRE DE LORGE DANS LES RATIONS de SeVRage PRÉcoce a 21 JOURS CHEZ Le PORCELET
}

\author{
A. AUMAitre \\ Station de Recherches sur l'Élevage des Porcs, \\ Centre national de Recherches zootechniques, I. N. R. A., \\ 78350 Jouy en Josas

\section{RÉSUMÉ}

L'orge est une céréale très bien tolérée par le porcelet sevré à 35 jours et nous avions précédemment souligné qu'elle améliorait l'état sanitaire des animaux par une diminution de la fréquence des diarrhées.

Nous avons entrepris une expérience en vue de comparer la valeur alimentaire de 3 orges (orge nue, orge maltée, orge normale) dans la ration de sevrage précoce à $2 \mathrm{I}$ jours en utilisant 60 porcelets placés au sol en loges, et I 2 porcelets placés en cage de digestibilité.

Préalablement à l'expérience (tabl. I) nous avons déterminé le taux de constituants membranaires des échantillons de céréales : l'orge nue est plus pauvre en constituants dosés par le détergent acide et plus riche en amidon. L'influence bénéfique de la granulation des régimes sur la dégradation in vitro de l'amidon par le suc pancréatique de porcelet a été montrée.

Les performances zootechniques des animaux montrent que l'orge est bien tolérée par le porcelet sevré à 2 I jours, mais que l'orge nue et l'orge maltéc n'améliorent pas significativement la croissance des animaux. Par contre, l'orge nue a méliore l'efficacité alimentaire de la ration d'environ 3 p. Ioo par rapport au témoin. L'utilisation digestive des régimes fait apparaître en accord avec le résultat précédent que la digestibilité moyenne de l'énergie brute de l'aliment est a méliorée dans le régime à base d'orge nue $(89,0$ p. Too contre 84,6 p. roo pour l'orge normale).

Des conclusions sont tirées sur le plan de rationnement des porcelets sevrés à 2 I jours, une variation de l'efficacité alimentaire avec l'âge (fig. 2) est soulignée. Enfin, il apparaît clairement que la granulation modifie l'amidon de l'orge et que le traitement de maltage n'apporte pas l'amélioration escomptée de l'utilisation de l'aliment. Par contre, l'orge nue est très bien appréciée par l'animal et présente une valeur énergétique supérieure à l'orge normale d'environ 4,5 p. Ioo. 


\title{
SUMMARY
}

\section{FEEDING VALUE OF BARLEY IN DIETS \\ OF PIGLETS WEANED AT 2 I DAYS}

Barley is well accepted by piglets weaned at 35 days and we previously demonstrated that it improves health of the animals reducing the frequency of diarrhoea.

The aim of the present study was to compare the feeding value of 3 types of barley (naked barley, malted barley, normal barley) in the early weaning diets (2I days) of 60 piglets reared on the floor in pens and of 12 piglets kept in digestibility crates.

Before the experiment (table $\mathrm{I}$ ) we determined the level of cell wall constituents in the barley samples : the lowest level of components, determined by the acid detergent (ADF) and the highest starch content was found in naked barley. It was shown that pelleting of the feed had a favourable effect on the in vitro breakdown of starch by the pancreatic fluid of piglets.

The performances of the animals showed that barley was well accepted by piglets weaned at 2 I days, but that naked barley and malted barley did not significantly improve the growth rate of the animals. On the other hand, naked barley improved the feed efficiency of the diet by about 3 per cent compared to the control. In agreement with the previous results, the mean digestibility of the crude energy of the feed was improved in diets containing naked barley (89.o per cent versus 84.6 per cent for normal barley).

Conclusions are drawn as regards feeding scales of piglets weaned at $2 \mathrm{I}$ days and variation with age (fig. 2) of the feed efficiency is emphasized. Finally, the results clearly show pelleting modifies the barley starch and that malting does not improve the utilization of the feed. On the other hand, naked barley is well accepted by the animal and its energy value exceeds that of normal barley by about 4.5 per cent.

\section{EFFET DE LA CUISSON ET DU BROYAGE SUR L'EFFICACITÉ NUTRITIVE DE L'ORGE MÙRE CHEZ LE PORC EN CROISSANCE}

\author{
J. DELORT-LAVAL
}

Laboratoire de Recherches sur la Conservation et l'Efficacité des Aliments, Centre national de Recherches zootechniques, I. N.R. A., 78350 Jouy en Josas

\section{RÉSUMÉ}

L'efficacité de l'orge pour le porc en croissance dépend de sa forme de présentation (farine fine ou grossière), de son traitement technologique et de la qualité de sa complémentation azotée.

Des bilans d'azote et de matière sèche sur porcs en croissance montrent que :

- Le traitement technologique (trempage de la céréale, ensuite séchée à l'air chaud) a pour effet de réduire la rétention azotée ; cette observation est en accord avec la moindre teneur en lysine totale et disponible de ces produits. Une complémentation de l'orge par un régime riche en lysine permet de remédier entièrement à cette insuffisance.

- Le broyage grossier (diamètre moyen des particules o,9-I,I $2 \mathrm{~mm}$ contre $0,39-0,47 \mathrm{~mm}$ ).

Annales de Zootechnie. - 1972. 